\title{
Gangliocytic paraganglioma in the ampulla of Vater: Case report and review of the literature
}

\author{
Adamantia Zizi-Sermpetzoglou ${ }^{1}$, Athanasios Marinis ${ }^{2 *}$, Despoina Myoteri ${ }^{1}$, Mavroudis Voultsos ${ }^{2}$, Vassiliki Savvaidou ${ }^{1}$ and Spyros Rizos $^{2}$ \\ Correspondence: drmarinis@gmail.com \\ ${ }^{1}$ Department of Pathology, and ${ }^{2}$ First Department of Surgery, “Tzaneion” General Hospital, 1 Afentouli and Zanni STR, \\ GR-18536, Piraeus, Greece.
}

\begin{abstract}
Gangliocytic paraganglioma (GP) is a rare tumor. Until today, only few cases have been reported. Usually GPs are encountered in the second portion of the duodenum, commonly occurring as small submucosal lesions. Histologically, they are characterized by the presence of three different types of cells: epithelioid cells with endocrine growth pattern, resembling paraganglioma or carcinoid tumor cells, spindle cells reminiscent of Schwann cells and ganglia or ganglion-like cells. Generally this tumor has a benign clinical course. Rarely, it may recur or metastasize to regional lymph nodes. We present a case of gangliocytic paraganglioma of the ampulla of Vater in a patient who underwent partial pancreaticoduodenectomy.
\end{abstract}

Keywords: Duodenum, immunohistochemical findings, ampulla of Vater, gangliocytic paraganglioma, neuroendocrine neoplasms.

\section{Background}

Gangliocytic paragangliomas (GPs) are extremely rare benign neuroendocrine tumors of the gastrointestinal tract [1] which occur primarily in the periampullary region in the second part portion of the duodenum [2], as small submucosal lesions. The clinical manifestations of the disease include abdominal pain, nausea, vomiting and gastrointestinal bleeding [2].The latter is due to possible mucosal erosion.

Histologically, GPs are characterized by the presence of epithelioid cells, spindle-shaped cells and ganglion-like cells [3]. Although these tumors have a benign behavior, a small number of cases have been reported to recur or metastasize to lymph nodes [3].

We report a case of GP in the ampulla of Vater in a patient hospitalized for cholangitis, as a result of obstruction of the common bile duct, which was treated by partial pancreaticoduodenectomy. The histological and immunohistochemical findings are briefly discussed along with a literature review.

\section{Case report}

A 77-year-old female patient was admitted to our emergency department due to right upper quadrant pain, fever and jaundice. Her past medical history was unremarkable. Diagnostic workup initially included abdominal computed tomography (CT) and magnetic resonance imaging (MRI) of the abdomen which demonstrated dilatation of the common bile duct. The patient underwent endoscopic retrograde cholangiopancreatography (ERCP) which showed a lesion at the ampulla of Vater, protruding intraluminally and giving "the impression of an impacted bile stone". Several biopsies were taken and the histologic examination showed an area of fibrosis with a spindle-cell element inside, whose nature could not be further characterized immunohistochemically due to insufficient specimen. Due to the diagnosis of a periampullary tumor of possible neuroendocrine origin we decided to proceed to a partial pancreaticoduodenectomy. The patient underwent a Whipple procedure.

Macroscopically, a solid well-circumscribed tumor was recognized, measuring $3 \mathrm{~cm}$ in greatest diameter, located at the ampulla of Vater without infiltration of the pancreatic parenchyma. The cut-surface of the tumor was grayish, firm and homogeneous. Neither necrosis nor hemorrhage was present. Sections of paraffin-embedded tissue were prepared and stained with hematoxylin and eosin (H/E).

The tumor was found to have three distinct patterns within, composed of nests of endocrine cells (Figure 1a), ganglion cells with abundant cytoplasm and spindle cells were found to surround tumor cells (Figure 1b). There was no mitotic activity, necrosis or infiltration of the pancreas. In sections from the 


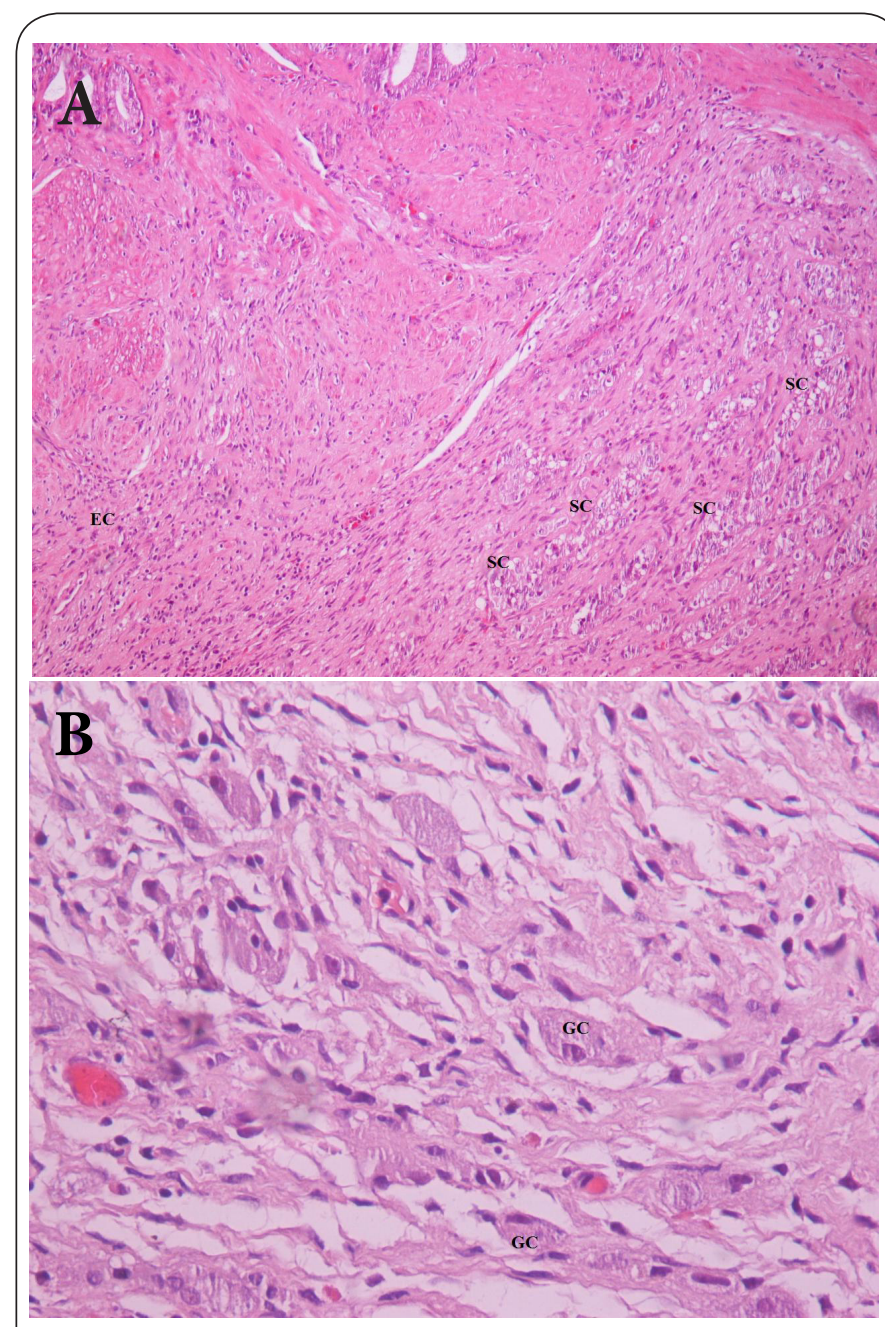

Figure 1. Gangliocytic paraganglioma (a) Epitheloid (EC) and spindle (SC) cells can be seen [HE x10], (b) Gangliocytic cells (GC) were found [HE x20].

pancreatic parenchyma, we recognized a pancreatic adenoma. Immunohistochemical analysis showed that tumor cells of epithelioid and ganglion cell types were positive for CD56 (Figure 2a) and synaptophysin (Figure 2b). In contrast spindleshaped cells showed positivity for S100p (Figure 2c), but not for synaptophysin and CD56. Neither cell type was positive for chromogranin A, cytokeratin AE1/AE3, epithelial membrane antigen (EMA). MIB-1 (Ki67) labeling index was estimated less than $1 \%$. The final diagnosis was gangliocytic paraganglioma in the ampulla of Vater. The patient did not receive any adjuvant radio- or chemotherapy. During on-going follow-up visits, no evidence of recurrence or metastasis was observed from May 2008 to April 2012.

\section{Discussion}

Gangliocytic paragangliomas (GPs) are rare benign tumors which were first described by Dahl et al., in 1957 [4]. Later Taylor and

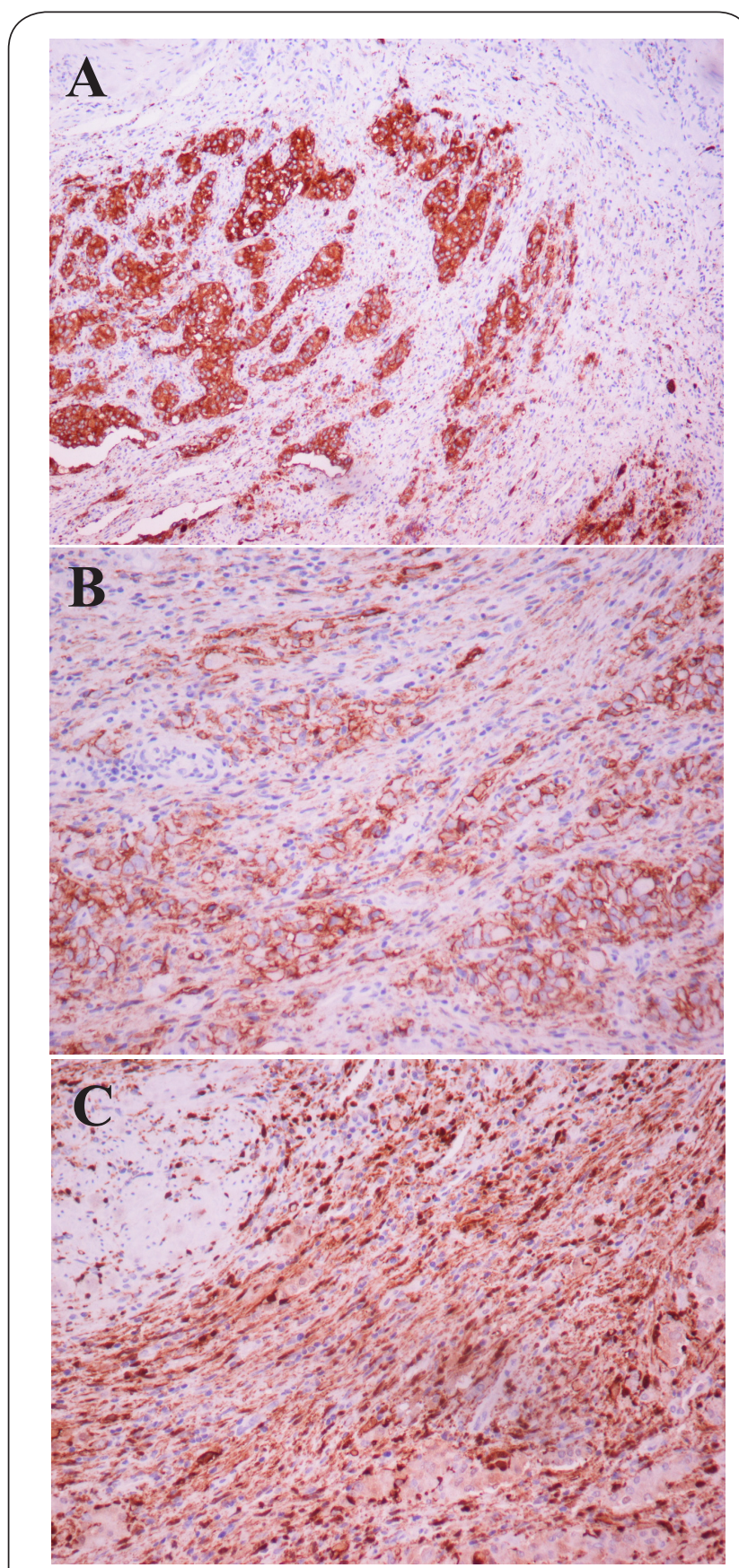

Figure 2. Epitheliod cells show a diffuse cytoplasmic positivity for CD56 (a) and synaptophysin (b). Spindle-shaped cells type show positivity for S100p (2c).

Helwig characterized these tumors as benign nonchromaffin paragangliomas [5]. In 1971 Kepes and Zacharias coined the term "gangliocytic paraganglioma" because of the recognition of common features of paraganglioma and ganglioneuroma [6]. According to the WHO classification of tumors of digestive tract (2010), gangliocytic paraganglioma is classified as a neuroendocrine neoplasm [7].

GPs are usually encountered in the periampullary region [2] 
of duodenum and rarely in the jejunum, pylorus, esophagus, pancreas and appendix. There have also been reported three cases of pulmonary GPs, that presented with chest pain, pneumonia and Cushing's syndrome respectively [8].

Clinically, GPs are usually asymptomatic. The symptoms, when present, depend on tumor location. Burke and Helwig in a review of 51 cases of GPs reported that the most common symptoms were: abdominal pain, gastrointestinal bleeding, melena, anemia, pyloric obstruction and obstruction of the bile duct [1]. Gastrointestinal hemorrhage is caused by submucosal erosion and ulceration at the site of the tumor. In these cases endoscopic biopsy may not be diagnostic because of the location of the tumor in the submucosa.

GPs are well defined by ultrasonography, visualized as an isoechoic mass, whereas on abdominal computer tomography they are demonstrated as solid and homogenous in appearance [4].

Grossly, GPs may be polypoid or sessile, solid or pendunculated. Their diameter ranges from $0.5 \mathrm{~cm}$ to 10 $\mathrm{cm}$ and they may be submucosal, nonencapsulated and well-circumscribed $[1,7]$. Histologically, they are composed of three components: epithelioid, ganglion and spindle cells in variable proportions. Mitotic figures are usually scanty and necrosis is absent. Immunohistochemistry is essential for the identification of the three cellular components $[2,4]$. The epithelioid cells are positive for neuron-specific enolase (NSE), synaptophysin and chromogranin. The expression of keratin in epithelioid cells in 50-60\% supports a neuroendocrine origin and distinguishes them from paragangliomas, which typically do not express keratin [10]. The ganglion cells express NSE and synaptophysin, whereas spindle cells are positive for S100p. [2,7]. Some authors have reported that epithelioid and ganglion cells stain for neuroendocrine peptides such as somatostatin, pancreatic polypeptide and serotonin $[9,10]$.

The histogenesis of GPs is controversial. There are two theories that explain their development. The first suggests that these tumors are of ectodermal origin, derived from pluripotent stem cells of neural crest. These cells are found in the glands of Lieberkuhn or celiac ganglion during fetal development [4]. The second theory proposes that GPs originate from an endodermal pluripotent progenitor that has the potential for divergent differentiation [10]. Some authors consider that GPs were hamartomas of endodermal and neuroectodermal origin [11].

The histological differential diagnosis of duodenal GPs includes well differentiated neuroendocrine carcinoma, ganglioneuroma, paraganglioma, and spindle cell malignant neoplasm (nerve sheath, smooth muscle and gastrointestinal stromal tumors) [9].

GPs typically are benign lesions and have good prognosis. Metastasis to regional lymph nodes is rare and thus does not affect the otherwise excellent outcome [3].

Endoscopic resection is the treatment of choice for these tumors. There are various techniques such as simple resection [2], delayed resection after hemostasis or excision by endoscopic mucosal resection with submucosal infiltration of saline solution [12]. However, when they present as periampullary tumors producing obstruction at the ampulla of Vater, with a FNA biopsy suggesting an underlying malignancy, a partial pancreaticoduodenectomy may be considered mandatory.

\section{Competing interests}

All authors declare that they do not have any financial or other competing interests.

\section{Author contributions}

All authors had substantial contributions to conception and design, acquisition of data, or analysis and interpretation of data; ZiziSerbetzoglou A and Marinis A equally contributed in drafting the article and revised it critically for important intellectual content; and, all authors gave final approval of the version to be published.

\section{Publication history}

Editor: Elizabeth HH, Yale University School of Medicine, USA.

EIC: G.J. Peters, VU University Medical Center, Netherlands.

Received: 12-June-2012 Revised: 22-June-2012

Accepted: 12-July-2012 Published: 02-Aug-2012

\section{References}

1. Burke AP, Helwig EB: Gangliocytic paraganglioma. Am J Clin Pathol 1989; 92;(1.);1-9. I PubMed

2. Scheithauer BW, Nora FE, LeChago J, Wick MR, Crawford BG, Weiland $\mathrm{LH}$, et al.: Duodenal gangliocytic paraganglioma. Clinicopathologic and immunocytochemical study of 11 cases. Am J Clin Pathol 1986; 86;(5.);559-65. I PubMed

3. Okubo Y, Yokose T, Tuchiya M, Mituda A, Wakayama M, Hasegawa C, et al.: Duodenal gangliocytic paraganglioma showing lymph node metastasis: a rare case report. Diagn Pathol 2010; 5;(27). I Article I PubMed Abstract | PubMed Full Text

4. Dahl EV, Waugh JM, Dahlin DC: Gastrointestinal ganglioneuromas; brief review with report of a duodenal ganglioneuroma. Am J Pathol 1957; 33;(5.);953-65. | PubMed Abstract | PubMed Full Text

5. Taylor HB, Helwig EB: Benign nonchromaffin paragangliomas of the duodenum. Virchows Arch Pathol Anat Physiol Klin Med 1962 . 335;(356-66. | Article I PubMed

6. Kepes JJ, Zacharias DL: Gangliocytic paragangliomas of the duodenum. A report of two cases with light and electron microscopic examination. Cancer 1971; 27;(1.);61-7. I Article I PubMed

7. Klppel G, Arnold R, Cappela C, Klimstra DS, J.Albores-Saavedra, et al; WHO Classification of Tumors of the Digestive System. Neuroendocrine neoplasms of the ampullary region. 2010. $4^{\text {th }}$ ed, Lyon, IARC p.92-94.

8. Palau MA, Merino MJ, Quezado M: Corticotropin-producing pulmonary gangliocytic paraganglioma associated with Cushing's syndrome. Hum Pathol 2006; 37;(5.);623-6. I Article | PubMed

9. Kwon J, Lee SE, Kang MJ, Jang JY, Kim SW: A case of gangliocytic paraganglioma in the ampulla of Vater. World J Surg Oncol 2010; 8;(42. | Article | PubMed Abstract | PubMed Full Text

10. Kheir SM, Halpern NB: Paraganglioma of the duodenum in association with congenital neurofibromatosis. Possible relationship. Cancer 1984; 53;(11.);2491-6. | Article I PubMed

11. Perrone T, Sibley RK, Rosai J: Duodenal gangliocytic paraganglioma. An immunohistochemical and ultrastructural study and a hypothesis concerning its origin. Am J Surg Pathol 1985; 9;(1.);31-41. I PubMed

12. Nagai T, Torishima R, Nakashima H, Tanahashi J, Iwata M, Ookawara H, et al.: Duodenal gangliocytic paraganglioma treated with endoscopic hemostasis and resection. J Gastroenterol 2004; 39;(3.);277-83. I Article | PubMed 